\title{
Effect of Accelerated Carbonation on the Mineral Phase of Alkaline Inorganic Waste
}

\author{
Namil UM ${ }^{1}$, Seong-Young NAM ${ }^{2}$, Thenepalli THRIVENI ${ }^{3}$ and Ji-Whan $\mathrm{AHN}^{3 *}$ \\ ${ }^{1}$ National Institute of Environmental Research, Environmental Resources Research, Incheon 404-708, \\ South Korea \\ ${ }^{2}$ Department of Energy Resources Engineering, Inha University, Incheon 420-751, South Korea \\ ${ }^{3}$ Mineral Resources Research Division, Korea Institute of Geoscience and Mineral Resources (KIGAM), \\ Daejeon 305-350, South Korea
}

\begin{abstract}
To effectively pre-treat the alkaline inorganic waste by carbonation reaction with $\mathrm{CO}_{2}$, it is necessary to understand a mineralogical change. This is because mineralogical changes serve as an important key to leaching behavior or stabilization of heavy metals, such as $\mathrm{Pb}, \mathrm{Cu}, \mathrm{Cr}$, and $\mathrm{Ni}$, contained in the inorganic waste, at the point of environmental influence. Therefore, in this study we investigated the chemical composition and mineralogical characteristics of municipal solid waste incineration bottom ash, which is a type of alkaline inorganic waste, and the material changed by the carbonation reaction in bottom ash. In addition, minerals affected by carbonation reactions were identified based on the ternary diagram of $\mathrm{Ca}-\mathrm{Al}-\mathrm{Si}$ in bottom ash. The relationship between mineralogical changes caused by carbonation reactions and stabilization of heavy metals was also examined.
\end{abstract}

Key words: Alkaline inorganic waste, MSWI bottom ash, Carbonation reaction, Ternary diagram of $\mathrm{Ca}-\mathrm{Al}-\mathrm{Si}$

\section{Introduction}

In South Korea, the industries of many fields have generated massive amounts of inorganic waste such as municipal waste incinerator bottom ash, municipal waste incinerator fly ash, steel slag, power plant bottom ash, waste concrete, and waste lime ${ }^{1}$. Most inorganic waste is buried in designated burial sites, resulting in a low recycling rate. While efforts are being made to utilize old burial sites as sports complexes or golf clubs, this is not a fundamental solution to the problem because it is difficult to acquire more sites from the limited land in Korea ${ }^{2}$. Thus, there is a need to facilitate waste management by increasing the recycling ratio instead of burying waste.

Carbonation processing technology with $\mathrm{CO}_{2}$ for effective pre-treatment of the inorganic waste has come under the spotlight as a means of

Paper presented at the $11^{\text {th }}$ Japan/Korea International Symposium on Resources Recycling and Materials Science, 17-19 June 2013, Osaka, Japan

Accepted 10 February, 2014

*e-mail: ahnjw@kigam.re.kr waste-resource recovery and is being developed for the stabilization of hazardous substances. In addition, the sequestration of $\mathrm{CO}_{2}$ into inorganic waste, along with geologic storage, offers storage of high amounts of $\mathrm{CO}_{2}$, and the research on $\mathrm{CO}_{2}$ based waste processing can be a solution to the challenge of reducing greenhouse gases amid the accelerated pace of global warming ${ }^{3,4}$.

In general, for applying carbonation technology to inorganic waste, the below conditions were used to separate the respective alkaline inorganic waste ${ }^{5}$ :

o Waste exists in solid form

o Waste is fully inorganic

- Waste is in an alkaline state $(\mathrm{pH}>8)$

- Waste contains non-carbonated $\mathrm{Ca}$ and $\mathrm{Al}$ compounds

Alkaline inorganic waste satisfying the above conditions easily engages in reactions with $\mathrm{CO}_{2}$. Using carbonation reactions to pre-treat inorganic waste has the effect of neutralizing the alkaline state, decomposition of insoluble chlorides, and stabilizing heavy metals. In order to understand 
these effects, it is essential to study mineralogical changes of alkaline inorganic waste ${ }^{6,7}$. Some important factors may be chemical composition and mineralogical characteristics of alkaline inorganic waste, material changes by carbonation reaction, and consequences on the environment. Therefore, in this study, the mineralogical characteristics and mineralogical changes caused by carbonation reaction with a focus on municipal waste incinerator bottom ash that is a type of alkaline inorganic waste. In addition, the material affected by carbonation reaction was identified based on the ternary diagram of $\mathrm{Ca}-\mathrm{Al}-\mathrm{Si}$ in bottom ash and the effect of heavy metals stabilization was also studied.

\section{Material and Methods}

\subsection{Material}

Samples of municipal waste incinerator bottom ash were obtained from an incinerator plant in Gwangmyeong-city in Gyeonggi province, Korea. In this incinerator plant, municipal waste was incinerated at a temperature of $1000^{\circ} \mathrm{C}$, and the moisture content of bottom ash was $30 \mathrm{w} / \mathrm{w} . \%$ as it is cooled by water-cooling after incineration. For particle separation, the moisture content of the bottom ash was kept below $1 \%$ by drying for 24 hours in an oven of $105^{\circ} \mathrm{C}$. For removal of large iron fraction, a magnetic separator with a magnetic strength of $0.38 \mathrm{~T}$ was used. After magnetic separation, the bottom ash was passed through a standard sieve to obtain particles larger than $4.75 \mathrm{~mm}, \quad 4.75-2.36 \mathrm{~mm}, \quad 2.36-1.18 \mathrm{~mm}$, $1.18-0.6 \mathrm{~mm}, 0.6-0.3 \mathrm{~mm}, 0.3-0.15 \mathrm{~mm}, 0.15-$ $0.075 \mathrm{~mm}$ and smaller than $0.075 \mathrm{~mm}$. An X-ray fluorescence spectrometer (Rigak TXRF 3726AI, Rigaku) was used to derive chemical compositions of bottom ash in each particle size. Fig. 1 shows the chemical composition of only $\mathrm{Ca}, \mathrm{Si}$, and $\mathrm{Al}$ in each particle size because of the most abundant in bottom ash. The concentration of $\mathrm{Si}$ increased with an increase in the particle size owing to the increased amounts of glass and synthetic ceramics, whereas $\mathrm{Ca}$ and $\mathrm{Al}$ increased with a decrease in the particle size.

\subsection{Leaching test}

A leaching test (standard method of the Korean Standard Leaching Procedure) was performed to measure the leached amount of $\mathrm{Cr}$ and $\mathrm{Cl}$ and the $\mathrm{pH}$ before and after carbonation. The bottom ash and diluted water were in the ratio of 1:10 (Solid/ Liquid, w/w.\%), and $\mathrm{HCl}$ was added to adjust the $\mathrm{pH}$ to 5.8-6.3. After stirring for 6 hours at $200 \mathrm{rpm}$, solid and liquid were separated by a fil-

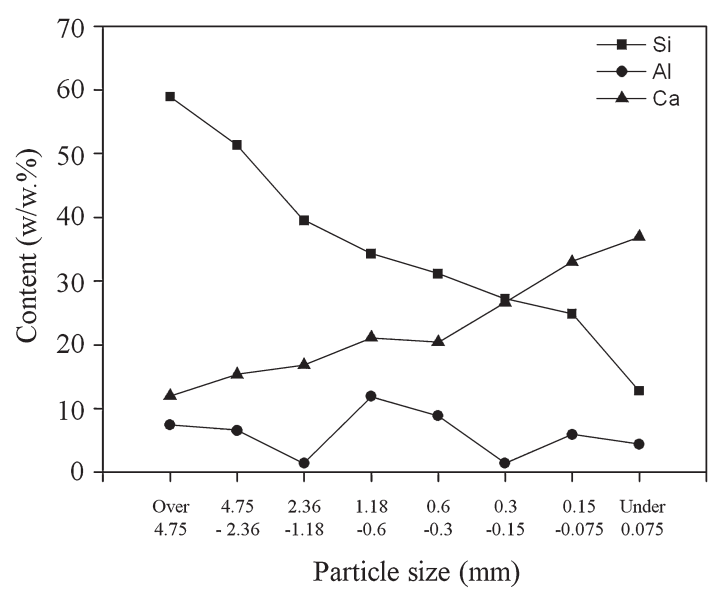

Fig. $1 \mathrm{Ca}, \mathrm{Al}$, and $\mathrm{Si}$ contents in the bottom ash as a particle size.

ter paper with a pore size of $0.5 \mathrm{um}$. The concentration of $\mathrm{Cr}$ and $\mathrm{Cl}$ and $\mathrm{pH}$ in the leachate were measured using an inductively coupled plasma atomic emission spectrometry (OPTIMA 5300DV, Perkin Elmer) and a pH electrode (SN5135011).

\subsection{Carbonation reaction}

To confirm the mineralogical change of the bottom ash before and after carbonation in terms of the three phases of $\mathrm{Ca}-\mathrm{Si}-\mathrm{Al}$, samples were prepared for carbonation reactions by selecting particles with a relatively small grain size of $0.6-0.3$ $\mathrm{mm}$ and because of well distribution of the three phases, as shown in Fig. 1. Cylindrical-type samples were created by mixing polymers and bottom ash, and then cut to reveal cross-sections. 105 particles on the surface of cross-sectional areas of samples were selected and numbered as shown in Fig. 2. Using the SEM and EDX (JSM-6400) equipment, compositional analysis was conducted to analyze the surface of cross-sectional areas. EDX was used for compositional analysis of the subjects with main elements $(\mathrm{Ca}, \mathrm{Si}, \mathrm{Al})$, heavy metal elements $(\mathrm{Fe}, \mathrm{Cu}, \mathrm{Cr}, \mathrm{Pb})$, and other elements $(\mathrm{Na}, \mathrm{K}, \mathrm{Cl}$, etc). Next, the samples were sandpapered to remove the Au coating on the surface of cross-sections. The carbonation experiments were performed in a $\mathrm{CO}_{2}$ incubation chamber to keep the $\mathrm{CO}_{2}$ percentage at $30 \%$ and the temperature at $25^{\circ} \mathrm{C}$ during $4 \mathrm{hrs}$ carbonation time, as shown in Fig. 3. The humidity of the reactor was maintained at $50 \%$. After carbonation reaction, mineralogical changes of 105 particles on the surface of cross-sections area were also observed using SEM. 


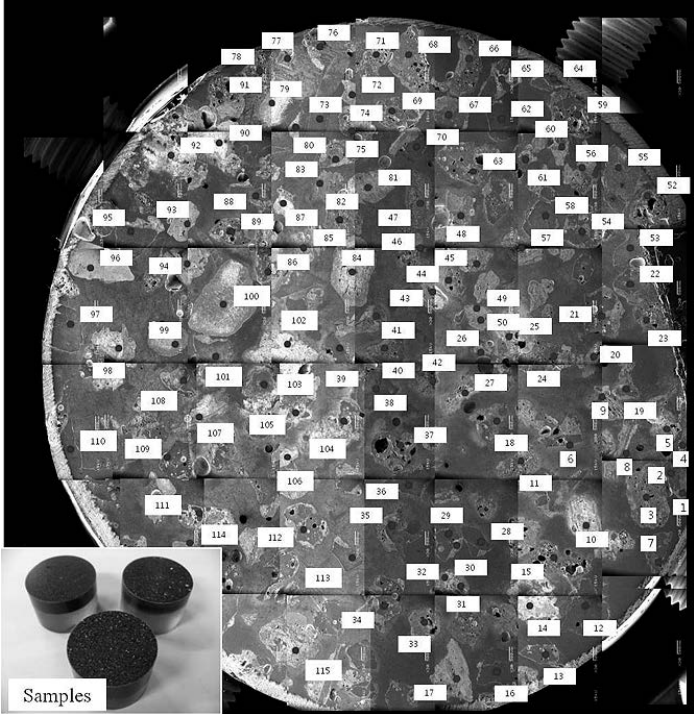

Fig. 2 Mapping of sample showing the section of bottom ash particles.

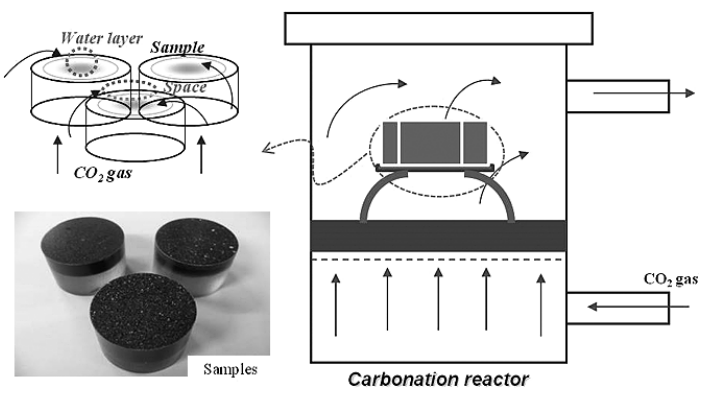

Fig. 3 Pictures of samples and carbonation equipment.

\section{Results and Discussion}

\subsection{Chemical composition and mineralogical characteristics of alkaline inorganic waste}

Many references ${ }^{8-11}$ with an analysis of mineral phases of municipal solid waste incinerator bottom ash explain that the bottom ash consists mostly of quartz, calcite, magnetite, hematite, gypsum, ettringite, akermanite, gehlenite, and cristobalite. These crystalline compounds are comprised of $\mathrm{Ca}, \mathrm{Al}$, and $\mathrm{Si}$, and traces of $\mathrm{Fe}, \mathrm{Na}, \mathrm{Mg}, \mathrm{Cl}$, and so on. The bottom ash is more than $40 \%$ glassy with particles of the vesicular, porous, coke, or crack type. The morphological characteristics of particles in bottom ash are closely related to exposure in air, contact with water, and the various type of cooling process after incineration, and these factors will form new substances by react- ing with those still remaining after incineration. The new substances are largely divided into silicate-type glassy substances and irregular or aggregate-type $\mathrm{Ca}-\mathrm{Al}$ compounds. In the point of view of the relationship between new substances and carbonation method with $\mathrm{CO}_{2}$, it is important to determine the conditions for carbonation reactions by confirming the chemical composition and mineral phase of each particle, and identifying minerals capable of easily reacting with $\mathrm{CO}_{2}$. Therefore, the cross-sectional areas of particles were observed for mineralogical characteristics, particle types, and whether or not carbonation has occurred. The measurements obtained are organized in Table 1. Fig. 4 is a graphical representation for $\mathrm{Ca}-\mathrm{Al}-\mathrm{Si}$ content ratio of 105 particles with main $\mathrm{Ca}, \mathrm{Al}$, and $\mathrm{Si}$ compounds.

As shown in Table 1, particle types are described as vesicular, silicate, porous, aggregate, whisker, coke, anisotropic, irregular, and crack. Silica-type minerals including silicate existed as aggregate and irregular types, and various forms of minerals of $\mathrm{Ca}$ and $\mathrm{Al}$, such as vesicular, porous, coke, and crack, were observed on the surface. To confirm the overall mineralogical characteristics of bottom ash, 105 particles were represented based on the ternary diagram of $\mathrm{Ca}-\mathrm{Al}-\mathrm{Si}$, as shown in Fig. 4. As seen in ternary diagram, there were hardly any minerals with a high proportion of $\mathrm{Al}$ due to the low $\mathrm{Al}$ content. Metal substances ( $\mathrm{Fe}, \mathrm{Cu}, \mathrm{Al}$, and $\mathrm{Cr}$ ) and other elements $(\mathrm{Na}, \mathrm{Mg}, \mathrm{K}$, and $\mathrm{Cl}$ ) were also detected in each particle as the form of metal fragments or metal compounds, while $\mathrm{Na}$ and $\mathrm{K}$ were soluble chlorides. $\mathrm{Cl}$ existed as soluble chlorides together with $\mathrm{Na}$ and $\mathrm{K}$, or as insoluble Friedel's salt with $\mathrm{Ca}^{12}$

More than $40 \%$ of bottom ash was minerals with high amounts of Si. They mostly exist as $\mathrm{SiO}_{2}$ or as a silicate-type compounds and these particles agglomerate with $\mathrm{Ca}-\mathrm{Al}$ compound to form large clusters. As for $\mathrm{Ca}$, it can be found as calcium carbonate, or as Friedel's salt and ettringite with Al. The high $\mathrm{pH}$ in bottom ash is caused by these $\mathrm{Ca}-\mathrm{Al}$ compounds and traces of $\mathrm{CaOH}$. Fig. 5 gives the main minerals with $\mathrm{Ca}-\mathrm{Al}-\mathrm{Si}$ in bottom ash. Fig. 5(a) is the typical $\mathrm{SiO}_{2}$ (silica) and silicate, Fig. 5(b) shows $\mathrm{Ca}-\mathrm{Al}$ compounds attached to silicate, and Fig. 5(c) and Fig. 5(d) represent calcium carbonate and $\mathrm{CaOH}_{2}$ respectively. Fig. 6, the same as Fig. 5(b), is the SEM and EDX analysis for $\mathrm{Ca}-\mathrm{Al}$ compounds attached around silicate-type particles. These aggregate particles are most commonly seen in $\mathrm{Ca}-\mathrm{Al}-\mathrm{Si}$ minerals with various porous structures of the 
Table 1 Content ratio of Ca-Al-Si, particle type, and carbonation reaction on the surface of bottom ash sample (including 105 particles)

\begin{tabular}{|c|c|c|c|c|c|c|}
\hline No. & carbonation & $\mathrm{Ca}(\%)$ & $\mathrm{Al}(\%)$ & $\mathrm{Si}(\%)$ & Particle type & Note \\
\hline 1 & Not & 100 & 0 & 0 & Vesicular & $\mathrm{CaCO}_{3}$ \\
\hline 2 & Not & 8 & 25 & 67 & Silicate & \\
\hline 3 & Not & 0 & 0 & 100 & Vesicular & $\mathrm{SiO}_{2}$ \\
\hline 4 & Not & 27 & 27 & 46 & Large porous & $\mathrm{Na}, \mathrm{Mg}$ contained \\
\hline 5 & Yes & 73 & 27 & 0 & Aggregate & $\mathrm{Cl}, \mathrm{Mg}$ contained \\
\hline 6 & Not & 11 & 27 & 62 & Silicate & \\
\hline 7 & Not & 19 & 6 & 75 & Silicate & \\
\hline 8 & Not & - & - & - & Whisker & Fe-metal \\
\hline 9 & Not & 75 & 25 & 0 & Coke & \\
\hline 10 & Not & - & - & - & Elliptic & Fe-metal and Fe-oxide \\
\hline 11 & Partial & 28 & 29 & 43 & Vesicular & \\
\hline 12 & Not & 8 & 23 & 69 & Silicate & \\
\hline 13 & Not & 10 & 25 & 65 & Silicate & \\
\hline 14 & Yes & - & - & - & Aggregate & $\mathrm{Na}-\mathrm{Zn}$ compound \\
\hline 15 & Not & 20 & 20 & 60 & Large porous & \\
\hline 16 & Not & 4 & 13 & 83 & Silicate & \\
\hline 17 & Not & 74 & 9 & 17 & Anisotropic & $\mathrm{Ca}-\mathrm{Zn}$ compound \\
\hline 18 & Not & 72 & 11 & 17 & Aggregate and porous & \\
\hline 19 & Not & 43 & 19 & 38 & Aggregate & \\
\hline 20 & Not & 42 & 33 & 25 & Aggregate and porous & \\
\hline 21 & Not & 20 & 13 & 67 & Aggregate and porous & \\
\hline 22 & Not & 8 & 34 & 58 & Elliptic & \\
\hline 23 & Not & 7 & 22 & 71 & Vesicular & \\
\hline 24 & Not & 12 & 19 & 69 & Aggregate and porous & \\
\hline 25 & Yes & 92 & 6 & 2 & Aggregate & $\mathrm{Na}, \mathrm{Cl}, \mathrm{Mg}$ contained \\
\hline 26 & Not & 45 & 55 & 0 & Irregular & \\
\hline 27 & Not & 42 & 33 & 25 & porous & \\
\hline 28 & Not & 7 & 13 & 80 & Silicate & Na contained \\
\hline 29 & Not & 6 & 12 & 82 & Silicate & Na contained \\
\hline 30 & Yes & 50 & 50 & 0 & Irregular & $\mathrm{Cl}$ contained \\
\hline 31 & Not & 0 & 0 & 100 & Vesicular & $\mathrm{SiO}_{2}$ \\
\hline 32 & Partial & 30 & 20 & 50 & Aggregate and crack & \\
\hline 33 & Partial & 42 & 25 & 33 & Large porous & $\mathrm{Cl}, \mathrm{Cr}, \mathrm{Fe}$ contained \\
\hline 34 & Partial & 24 & 19 & 57 & Aggregate & \\
\hline 35 & Partial & 22 & 17 & 61 & Aggregate & Na contained \\
\hline 36 & Not & 20 & 7 & 73 & Silicate & Na contained \\
\hline 37 & Not & 26 & 33 & 40 & Large porous & \\
\hline 38 & Not & 15 & 8 & 77 & Silicate & Na contained \\
\hline 39 & Not & 9 & 8 & 83 & Silicate & Na contained \\
\hline 40 & Not & 27 & 6 & 67 & Silicate and porous & Na contained \\
\hline 41 & Not & 21 & 36 & 43 & Crack and porous & \\
\hline 42 & Not & 16 & 18 & 66 & Silicate and porous & \\
\hline 43 & Yes & 82 & 6 & 12 & Irregular & \\
\hline 44 & Not & 22 & 8 & 70 & Silicate and large porous & \\
\hline 45 & Not & 54 & 18 & 28 & Aggregate and large porous & Fe-iron contained \\
\hline 46 & Not & 13 & 47 & 40 & Aggregate and large porous & \\
\hline 47 & Not & 0 & 47 & 53 & Irregular and porous & \\
\hline 48 & Not & 55 & 27 & 18 & Aggregate and crack & Fe-iron contained \\
\hline 49 & Not & 98 & 1 & 1 & Irregular and porous & $\mathrm{CaCO}_{3}$ \\
\hline 50 & Not & 33 & 44 & 23 & Irregular and porous & \\
\hline 51 & Not & 97 & 3 & 0 & Vesicular & $\mathrm{CaCO}_{3}$ containing $\mathrm{Cl}$ \\
\hline 52 & Not & 27 & 18 & 55 & Large porous & \\
\hline 53 & Not & 9 & 3 & 88 & Silicate & Na contained \\
\hline 54 & Partial & 16 & 28 & 56 & Irregular and large porous & $\mathrm{Fe}, \mathrm{Na}$ contained \\
\hline 55 & Not & 0 & 35 & 65 & Silicate & Na contained \\
\hline 56 & Partial & 45 & 27 & 28 & Aggregate and porous & \\
\hline 57 & Not & 80 & 16 & 4 & Aggregate and porous & \\
\hline 58 & Not & 0 & 0 & 100 & Silicate & \\
\hline
\end{tabular}


Table 1 (continued)

\begin{tabular}{|c|c|c|c|c|c|c|}
\hline No. & carbonation & $\mathrm{Ca}(\%)$ & $\mathrm{Al}(\%)$ & $\mathrm{Si}(\%)$ & Particle type & Note \\
\hline 59 & Not & 17 & 16 & 67 & Aggregate and large porous & $\mathrm{Mg}, \mathrm{Na}$ contained \\
\hline 60 & Not & 59 & 12 & 29 & Aggregate and porous & \\
\hline 61 & Not & 24 & 9 & 67 & Aggregate and large porous & $\mathrm{Na}$ contained \\
\hline 62 & Not & 0 & 0 & 100 & Silicate & \\
\hline 63 & Not & 32 & 10 & 58 & Aggregate and large porous & $\mathrm{Na}, \mathrm{Mg}$ contained \\
\hline 64 & Not & 10 & 4 & 86 & Silicate and crack & $\mathrm{Na}$ contained \\
\hline 65 & Not & 28 & 0 & 72 & Aggregate & \\
\hline 66 & Not & 57 & 29 & 14 & Vesicular & \\
\hline 67 & Not & 43 & 21 & 36 & Irregular & Fe-oxide contained \\
\hline 68 & Not & - & - & - & Vesicular & $\begin{array}{l}\mathrm{Na} \text { and } \mathrm{Mg} \text { compound } \\
\text { containing Fe-oxide }\end{array}$ \\
\hline 69 & Partial & 14 & 7 & 79 & Aggregate and porous & \\
\hline 70 & Partial & 36 & 21 & 43 & Aggregate and large porous & Fe-oxide contained \\
\hline 71 & Not & 50 & 25 & 25 & Vesicular & \\
\hline 72 & Not & 24 & 6 & 70 & Aggregate & \\
\hline 73 & Not & 95 & 4 & 1 & Irregular and porous & $\mathrm{CaCO}_{3}$ \\
\hline 74 & Not & 33 & 25 & 42 & Aggregate & \\
\hline 75 & Not & 39 & 30 & 31 & Aggregate and porous & \\
\hline 76 & Not & 24 & 12 & 64 & Aggregate and porous & \\
\hline 77 & Not & 35 & 18 & 47 & Aggregate and large porous & $\mathrm{Na}, \mathrm{Mg}$ contained \\
\hline 78 & Not & 0 & 0 & 100 & Vesicular & $\mathrm{SiO}_{2}$ \\
\hline 79 & Not & 94 & 3 & 3 & Irregular and porous & $\mathrm{CaCO}_{3}$ \\
\hline 80 & Not & 32 & 7 & 61 & Aggregate & \\
\hline 81 & Yes & 73 & 12 & 15 & Irregular and crack & \\
\hline 82 & Not & 19 & 35 & 46 & Vesicular & \\
\hline 83 & Not & 39 & 61 & 0 & Anisotropic & $\mathrm{Zn}$ contained \\
\hline 84 & Yes & 71 & 14 & 15 & Irregular and crack & \\
\hline 85 & Not & 99 & 0 & 1 & anisotropic & Na contained \\
\hline 86 & Partial & 32 & 23 & 45 & Aggregate and large porous & \\
\hline 87 & Yes & 92 & 5 & 3 & Irregular and porous & Na contained \\
\hline 88 & Not & 0 & 0 & 100 & Silicate & \\
\hline 89 & Not & 34 & 7 & 59 & Aggregate and large porous & $\mathrm{Fe}, \mathrm{Na}, \mathrm{Cl}$ contained \\
\hline 90 & Yes & 95 & 5 & 0 & Irregular and crack & $\mathrm{Cl}$ contained \\
\hline 91 & Not & 46 & 21 & 33 & Vesicular and large porous & $\mathrm{Na}, \mathrm{Mg}, \mathrm{Cl}, \mathrm{K}$ contained \\
\hline 92 & Not & 10 & 0 & 90 & Aggregate and large porous & $\mathrm{Mg}-\mathrm{Si}$ compound \\
\hline 93 & Not & 96 & 4 & 0 & Irregular and porous & Ca-P compound \\
\hline 94 & Weak & 69 & 24 & 7 & Irregular and porous & $\mathrm{Na}, \mathrm{Cl}$ contained \\
\hline 95 & Not & 1 & 1 & 98 & Silicate & \\
\hline 96 & Not & 97 & 0 & 3 & Silicate & $\mathrm{K}$ contained \\
\hline 97 & Not & 0 & 0 & 100 & Silicate & \\
\hline 98 & Weak & 60 & 40 & 0 & Aggregate, porous and crack & $\mathrm{Na}-\mathrm{Cu}$ mineral contained \\
\hline 99 & Weak & 77 & 23 & 0 & Irregular & \\
\hline 100 & Not & 100 & 0 & 0 & Irregular and crack & \\
\hline 101 & Not & 22 & 17 & 61 & Aggregate and porous & Fe-iron contained \\
\hline 102 & Yes & 100 & 0 & 0 & Irregular and crack & \\
\hline 103 & Not & 0 & 100 & 0 & Irregular and porous & Amorphous Al-oxide \\
\hline 104 & Yes & 59 & 35 & 6 & Irregular and crack & $\mathrm{Na}, \mathrm{Mg}, \mathrm{Cl}, \mathrm{K}$ contained \\
\hline 105 & Yes & 79 & 18 & 3 & Irregular and crack & $\mathrm{Na}, \mathrm{Cl}$ contained \\
\hline 106 & Not & 5 & 22 & 73 & Vesicular & $\mathrm{Mg}, \mathrm{Cl}, \mathrm{Mg}$ contained \\
\hline 107 & Yes & 70 & 27 & 3 & Irregular and crack & $\mathrm{Na}, \mathrm{Cl}, \mathrm{K}$ contained \\
\hline 108 & Not & 40 & 25 & 35 & Aggregate and porous & $\mathrm{Mg}$ contained \\
\hline 109 & Not & 28 & 11 & 61 & Irregular and large porous & Na contained \\
\hline 110 & Not & 0 & 0 & 100 & Silicate & \\
\hline 111 & Partial & 30 & 32 & 38 & Aggregate & $\mathrm{Na}, \mathrm{Mg}, \mathrm{Cl}, \mathrm{K}$ contained \\
\hline 112 & Not & 30 & 13 & 57 & Aggregate and large porous & $\mathrm{Na}, \mathrm{Mg}$ contained \\
\hline 113 & Not & 0 & 0 & 100 & Silicate & \\
\hline 114 & Not & 98 & 1 & 1 & Irregular and porous & \\
\hline 115 & Not & 13 & 19 & 68 & Vesicular and crack & $\mathrm{Na}, \mathrm{K}$ contained \\
\hline
\end{tabular}




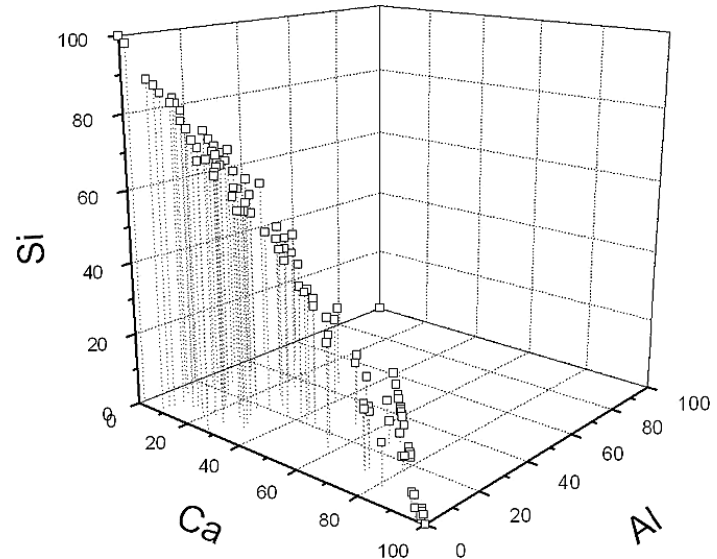

Fig. 4 Diagram of $\mathrm{Ca}, \mathrm{Al}$, and $\mathrm{Si}$ content ratio in each bottom ash particle.
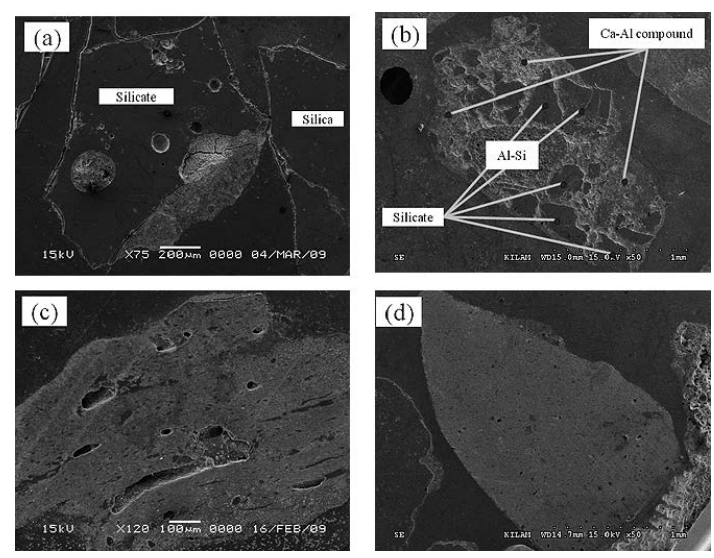

Fig. 5 SEM analysis of main minerals with Ca-Al-Si in bottom ash; (a) typical silica $\left(\mathrm{SiO}_{2}\right)$ and silicate, (b) Ca-Al compounds attached to silicate, (c) calcium carbonate, and (d) $\mathrm{Ca}(\mathrm{OH})_{2}$.

bottom ashes generated from incinerator after incineration process.

Next, the characteristics of metal substances in bottom ash were confirmed. Fe-material, which has the highest distribution among metals, accounted for more than $10 \%$ of bottom ash. Most $\mathrm{Fe}$ was Fe-metal and Fe-oxide that was formed by oxidation from the corrosion of Fe-iron. The majority of Fe-metal coated with Fe-oxide existed independently, whereas some Fe-oxide was aggregated with other particles and difficult to separate by magnetic separation ${ }^{13}$. Fig. 7(a) and Fig. 7(b) show that Fe-metal and Fe-oxide intertwined with vitreous materials. As shown in Fig. 7(c), the picture shows Al-metal agglomerating with other compounds. This picture may be evidence about the low separation ratio using an
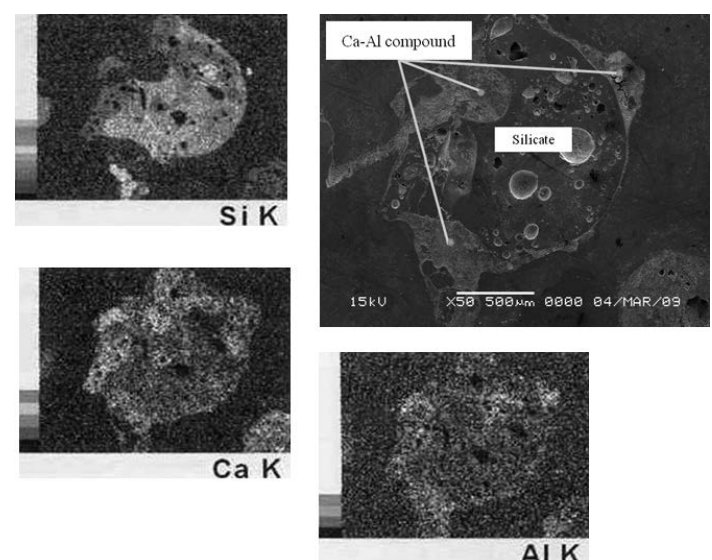

Fig. 6 SEM and EDS analysis of silicate surrounded with Ca-Al compound.
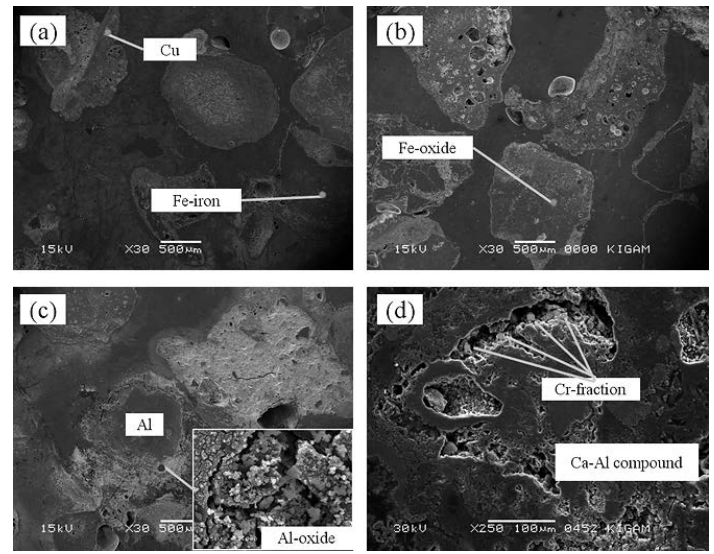

Fig. 7 SEM analysis of constituents with heavy metals; (a) $\mathrm{Fe}$-metal and $\mathrm{Cu}$-metal existing as a whiskertype, (b) Fe-oxide intertwined with vitreous materials, (c) Al-metal agglomerating with other compounds, (d) Cr-metal existing in the inner porous layer of $\mathrm{Ca}-\mathrm{Al}$ compounds.

eddy current separator as well as the surface oxidized as $\mathrm{Al}$-oxide ${ }^{14}$. Thus, more research on $\mathrm{Al}$ detection and separation has to be studied, because that cracks are formed if Al-containing bottom ash is reused for buildings or pavements. In Fig. 7(a), we can see Cu-metal existing as a whisker type and being surrounded by vitreous materials. Cr-metal, as presented in Fig. 7(d), was found in the inner porous layer of $\mathrm{Ca}-\mathrm{Al}$ compounds. The existence of heavy metals in bottom ash particles must be determined in more detail since such metals involve a risk of leaching into solution. 


\subsection{Effect of accelerated carbonation on the mineral phase}

The bottom ash produces unstable $\mathrm{Ca}-\mathrm{Al}$ compounds during the water-cooling process (cooling down the incinerated high-temperature bottom ash before it goes to the landfill) following incineration. Because these substances contain various metal components, they can play an important role in the leaching of heavy metals, which have an environmental impact. These compounds are generated in alkaline bottom ash, as follows below.

In the case of $\mathrm{Ca}$, it changes to $\mathrm{CaO}$ when incinerated at a temperature of $1000^{\circ} \mathrm{C}$, and the water cooling process appears to control the formation of portlandite $\left(\mathrm{Ca}(\mathrm{OH})_{2}\right)$. In addition, ettringite $\left(\mathrm{Ca}_{6} \mathrm{Al}_{2}\left(\mathrm{SO}_{4}\right)_{3}(\mathrm{OH})_{12} \cdot 26 \mathrm{H}_{2} \mathrm{O}\right)$ and Friedel's salt (or hydrocalumite; $\mathrm{Ca}_{2} \mathrm{Al}(\mathrm{OH})_{6} \mathrm{Cl} \cdot 2 \mathrm{H}_{2} \mathrm{O}$ ) are controlled by the water cooling process, as they are in an environmental condition in which they can be formed. Regarding the formation and properties of ettringite, the stability domain for ettringite generally lies between $\mathrm{pH} 10.5$ and $\mathrm{pH}$ 13. Its formation is generally favored over mono-sulfate at low temperatures, below $50^{\circ} \mathrm{C}$. In the case of Friedel'salt, it is synthesized in the Ca-Al-Cl system at $65^{\circ} \mathrm{C}$ and the $\mathrm{pH}$ is kept constant at over 11.5 according to the following equation ${ }^{15,16}$ :

$$
\begin{aligned}
& \text { Ettringite: } \\
& \qquad \begin{array}{l}
6 \mathrm{Ca}^{2+}+2 \mathrm{Al}^{3+}+3 \mathrm{SO}_{4}^{2-}+38 \mathrm{H}_{2} \mathrm{O} \\
\quad \rightarrow 12 \mathrm{H}^{+}+\mathrm{Ca}_{6} \mathrm{Al}_{2}\left(\mathrm{SO}_{4}\right)_{3}(\mathrm{OH})_{12} \cdot 26 \mathrm{H}_{2} \mathrm{O}
\end{array}
\end{aligned}
$$

Friedel's salt:

$$
\begin{aligned}
& 2 \mathrm{Ca}^{2+}+\mathrm{Al}^{3+}+\mathrm{Cl}^{-}+8 \mathrm{H}_{2} \mathrm{O} \\
& \quad \rightarrow 6 \mathrm{H}^{+}+\mathrm{Ca}_{2} \mathrm{Al}(\mathrm{OH})_{6} \mathrm{Cl} \cdot 2 \mathrm{H}_{2} \mathrm{O} .
\end{aligned}
$$

$\mathrm{Ca}(\mathrm{OH})_{2}$, ettringite, and Friedel's salt are unstable Ca-Al compounds in bottom ash that show distinct changes in carbonation reactions with $\mathrm{CO}_{2}$. To explain the characteristics of the variation in the mineral phase of bottom ash via a carbonation reaction, the XRD diffraction of before and after carbonation reaction has to be investigated. The mineral phases of bottom ash obviously changed with carbonation reaction have been reported in the literatures ${ }^{11,17,18}$. The decomposition of $\mathrm{Ca}(\mathrm{OH})_{2}$, ettringite, and Friedel's salt from carbonation is as follows ${ }^{19,20}$.

$$
\begin{gathered}
\mathrm{Ca}(\mathrm{OH})_{2}+\mathrm{CO}_{2} \rightarrow \mathrm{CaCO}_{3}+\mathrm{H}_{2} \mathrm{O} . \\
\mathrm{Ca}_{6} \mathrm{Al}_{2}\left(\mathrm{SO}_{4}\right)_{3}(\mathrm{OH})_{12} \cdot 26 \mathrm{H}_{2} \mathrm{O}+3 \mathrm{CO}_{2} \\
\rightarrow 3 \mathrm{CaCO}_{3}+3\left[\mathrm{CaSO}_{4} \cdot 2 \mathrm{H}_{2} \mathrm{O}\right] \\
+\mathrm{Al}_{2} \mathrm{O}_{3} \cdot \mathrm{xH}_{2} \mathrm{O}+(26-\mathrm{x}) \mathrm{H}_{2} \mathrm{O} .
\end{gathered}
$$

$$
\begin{gathered}
2\left[\mathrm{Ca}_{2} \mathrm{Al}(\mathrm{OH})_{6} \mathrm{Cl} \cdot 2 \mathrm{H}_{2} \mathrm{O}\right]+3 \mathrm{CO}_{2} \\
\rightarrow 3 \mathrm{CaCO}_{3}+\mathrm{Al}_{2} \mathrm{O}_{3} \cdot \mathrm{xH}_{2} \mathrm{O} \\
+\mathrm{CaCl}_{2}+(10-\mathrm{x}) \mathrm{H}_{2} \mathrm{O} .
\end{gathered}
$$

As shown in chemical reactions, calcite became the main crystalline phase in the carbonated bottom ash upon the decomposition of portlandite, ettringite, and Friedel's salt. These reactions may be interpreted as suggesting the possibility of the formation of a new amorphous product, Al-oxide, which forms due to the dissolution of ettringite and Friedel's salt. As presented in Table 1, each particle in bottom ash was checked for carbonation. Fig. 8 shows the ternary diagram of $\mathrm{Ca}, \mathrm{Al}$, and $\mathrm{Si}$ content ratio in each particle after carbonation reaction, like Fig. 4. As a result, most minerals that have been subject to carbonation were found to exist as $\mathrm{Ca}-\mathrm{Al}$ compounds. This result indicates that the aforementioned decomposition reactions of $\mathrm{Ca}(\mathrm{OH})_{2}$, ettringite, and Friedel's salt are main carbonation reactions in bottom ash. Fig. 9 shows SEM analysis of the surface of particles affected by carbonation reaction. They can be broadly classified into three types. Carbonation reactions can occur either on the entire surface of $\mathrm{Ca}-\mathrm{Al}$ compounds or on part of the surface of $\mathrm{Ca}$ $\mathrm{Al}$ compounds agglomerating with silicate or other materials, and this is believed to be caused by the carbonation reaction of ettringite and Friedel's salt with $\mathrm{CO}_{2}$. In addition, the most active reactions took place in $\mathrm{Ca}(\mathrm{OH})_{2}$, which is illustrated in Fig. 9(c).

\subsection{Carbonation effect on heavy metal stabili- zation}

As mentioned above, the three substances with $\mathrm{Ca}(\mathrm{OH})_{2}$, ettringite, and Friedel's salt are decom-

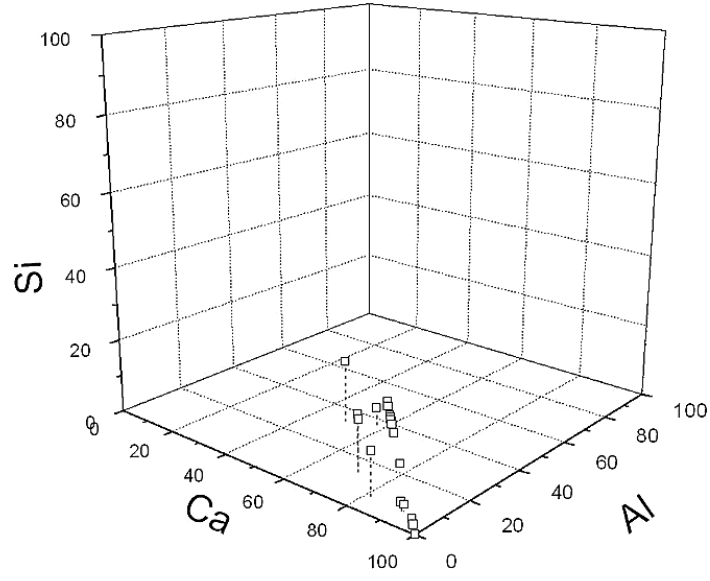

Fig. 8 Diagram of $\mathrm{Ca}, \mathrm{Al}$, and $\mathrm{Si}$ content ratio in each bottom ash particle after carbonation reaction. 

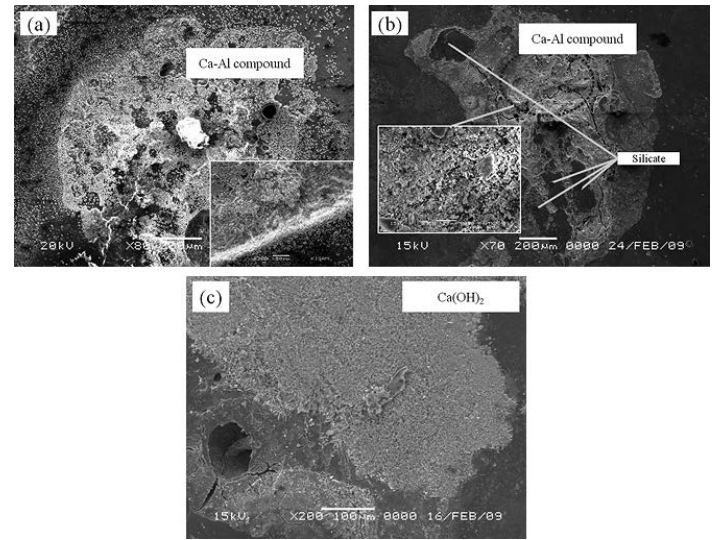

Fig. 9 SEM analysis of three types of the particles affected by carbonation reaction; (a) occurring on the entire surface of $\mathrm{Ca}-\mathrm{Al}$ compound, (b) occurring on part of the surface of Ca-Al compound agglomerating with silicate, (c) occurring on the surface of $\mathrm{Ca}(\mathrm{OH})_{2}$.

posed after carbonation, producing $\mathrm{CaCO}_{3}$ and $\mathrm{Al}_{2} \mathrm{O}_{3}$. In particular, $\mathrm{Al}_{2} \mathrm{O}_{3}$ is known as an amorphous material, highly adhesive substance with heavy metal ions. As can be seen from many references ${ }^{6,11,21}$ about the stabilization of heavy metals according to carbonation reaction, the generation of $\mathrm{CaCO}_{3}$ and amorphous $\mathrm{Al}_{2} \mathrm{O}_{3}$ has a significant effect on the control of heavy metal's leaching. Fig. 10 is the SEM image showing mineral changes caused by carbonation reaction on the surface of particles containing Cr-fractions, and can be used as evidence in explaining the effect of carbonation on the stabilization of heavy metal. As seen in Fig. 10, we could confirm that Cr-fractions exist in the inner porous layer of $\mathrm{Ca}-\mathrm{Al}$ compounds before carbonation reaction, but new and irregularly-shaped substances with $\mathrm{CaCO}_{3}$ and amorphous $\mathrm{Al}_{2} \mathrm{O}_{3}$ are wrapped around $\mathrm{Cr}$-fractions after carbonation reaction. This provides evidence of the morphological changes in the particles in what is termed the encapsulation effect $^{21,22}$.
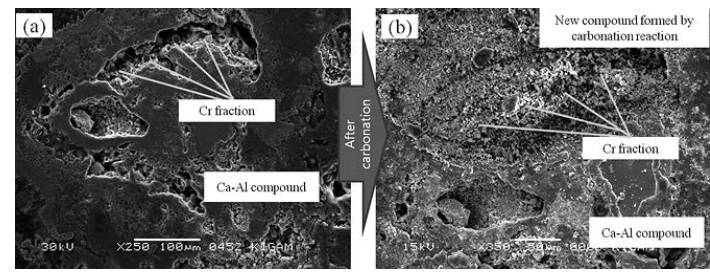

Fig. 10 SEM analysis of Ca-Al compound with Crmaterial (a) before and (b) after carbonation reaction.
Table 2 Leaching concentrations of $\mathrm{Cr}$, the removal ratio of $\mathrm{Cl}$, and $\mathrm{pH}$ changes caused by carbonation reaction

\begin{tabular}{lccc}
\hline & $\begin{array}{c}\text { Leaching } \\
\text { concentration } \\
\text { of Cr }(\mathrm{mg} / \mathrm{L})\end{array}$ & $\begin{array}{c}\text { Removal ratio } \\
\text { of Cl } \\
\text { (wt/wt.\%) }\end{array}$ & $\mathrm{pH}$ \\
\hline $\begin{array}{l}\text { Before } \\
\text { carbonation }\end{array}$ & 0.40 & 0 & 12.0 \\
\hline $\begin{array}{l}\text { After } \\
\text { carbonation }\end{array}$ & 0.01 & 92.4 & 8.9 \\
\hline
\end{tabular}

Regarding the confirmation of $\mathrm{Cr}$ leaching behavior, $\mathrm{Cl}$ and $\mathrm{pH}$, and $\mathrm{Cr}$ behaviors during $4 \mathrm{hrs}$ of carbonation reaction time were investigated. Table 2 shows the leaching concentrations of $\mathrm{Cr}$, the removal ratio of $\mathrm{Cl}$, and $\mathrm{pH}$ changes caused by carbonation reaction. We can consider the variation of the $\mathrm{pH}$ as a function of carbonation time. Before the carbonation reaction, bottom ash is highly alkaline with a $\mathrm{pH}$ of 12 due to the presence of ettringite, hydrocalumite, and portlandite, but $\mathrm{pH}$ falls when these substances are decomposed during initial carbonation. Eventually, the $\mathrm{pH}$ falls below 9 after carbonation reactions, and the value is determined by the newly formed calcite, amorphous $\mathrm{Al}_{2} \mathrm{O}_{3}$, and gypsum. The decomposition of ettringite and hydrocalumite from $\mathrm{CO}_{2}$ reactions also affects the removal ratio of $\mathrm{Cl}$ from the bottom ash. As shown in Table 2, the removal ratio of $\mathrm{Cl}$ increased during the carbonation reaction. In the case of $\mathrm{Cr}$, it decreased until below $0.1 \mathrm{mg} / \mathrm{L}$. Cr-stabilization is supported by two findings by the carbonation reaction. First, the carbonation reaction is to decrease the $\mathrm{pH}$ and to form insoluble $\mathrm{Cr}$-material that contributes to a reduction of the leaching. Secondly, the adsorbent compound, which is amorphous Al-material formed by the carbonation reaction and has high affinity of $\mathrm{Cr}$, in the bottom ash, controls the leaching of $\mathrm{Cr}$. In addition, the encapsulation effect, mentioned in Fig. 10, occurring on the surface of the bottom ash particles results in more effective stabilization of $\mathrm{Cr}$ leaching behavior.

\section{Conclusions}

In this study, the effect of accelerated carbonation on the mineral phase of alkaline inorganic waste was investigated. In order to confirm the carbonation effect, the important factors with the chemical composition and the mineralogical characteristics of alkaline inorganic waste, the accelerated carbonation on the mineral phase were also examined with focus on municipal waste inciner- 
ator bottom ash that is a type of alkaline inorganic waste.

In this result, the bottom ash was largely divided into silicate-type glassy material and aggregate-type $\mathrm{Ca}-\mathrm{Al}$ compounds. After carbonation processing with $\mathrm{CO}_{2}$, the carbonation reaction in bottom ash could occur on the surface of $\mathrm{Ca}-\mathrm{Al}$ compounds agglomerating with silicate, other materials, and heavy metals, and this is to be caused by the carbonation reaction of ettringite, Friedel's salt, and $\mathrm{Ca}(\mathrm{OH})_{2}$ with $\mathrm{CO}_{2}$.

In addition, we also confirmed the effect of heavy metals stabilization in bottom ash during carbonation reaction, and this result showed that the leaching of $\mathrm{Cr}$, on behalf of heavy metals, started to decrease after carbonation reaction and fell under the initial value of $\mathrm{Cr}$ leaching in the untreated bottom ash. Calcium carbonate and amorphous Al-oxide formed by decomposition of $\mathrm{Ca}(\mathrm{OH})_{2}$, ettringite, and Friedel's salt has a significant influence on the leaching characteristics of Cr. The encapsulation effect, showing the amorphous Al-materials precipitated on the surface of the carbonated bottom ash particles, allowed for more effective stabilization of the leaching behavior of $\mathrm{Cr}$.

\section{Acknowledgment}

This research was supported by a grant (2013) from the Energy Technology Development Program (2013T100100021) funded by the Ministry of Trade, Industrial and Energy of the Korean government.

\section{References}

1. J.W. Ahn: Treatment technologies of municipal solid waste incineration (MSWI)-bottom ash: Journal of Korean Inst. of Resources Recycling, 43(3), pp. 258-267 (2006)

2. N.I. Um, G.C. Han, K.S. You, H.S. Kim, J.W. Ahn: Characteristic of treatment process from municipal solid waste incineration (MSWI) bottom ash, The Korean Society for Geosystem Engineering, 46(6), pp. 767-775 (2009)

3. R.M. Santos, J.V. Bouwel, E. Vandevelde, G. Mertens, J. Elsen, T.V. Gerven: Accelerated mineral carbonation of stainless steel slags for $\mathrm{CO}_{2}$ storage and waste valorization: Effect of process parameters on geochemical properties, International Journal of Greenhouse Gas Control, 17, pp. 32-45 (2013)

4. D. Zingaretti, G. Costa, R. Baciocchi: Assessment of the Energy Requirements for $\mathrm{CO}_{2}$ storage by carbonation of industrial residues. Part 1: Definition of the process layout, Energy Procedia, 37, pp. 5850-5857 (2013)

5. S.Y. Pan, E.E. Chang, P.C. Chiang: $\mathrm{CO}_{2}$ capture by accelerated carbonation of alkaline wastes: A review on its principles and applications, Aerosol and Air Quality Research, 12, pp. 770-791 (2012)

6. A. Polettini and R. Pomi: The leaching behavior of incinerator bottom ash as affected by accelerated ageing, Journal of Hazardous Materials, B113, pp. 209-215 (2004)

7. J.W. Ahn, N.I. Um, G.C. Han, K.S. You, H.C. Cho: Effect of carbonation in removal of chloride from municipal solid waste incineration bottom ash, Geosystem Engineering, 9(4), pp. 87-90 (2006)

8. S.V. Vassilew, C.G. Vassileva, A.I. Karayigit, Y. Bulut, A. Alastuey, X. Querol: Phase-mineral and chemical composition of composite samples from feed coals, bottom ashes and fly ashes at the soma power station, Turkey, Coal Geology, 61, pp. 3563 (2005)

9. Y. Wei, T. Shimaoka, A. Saffarzadeh, F. Takahashi: Mineralogical characterization of municipal solid waste incineration bottom ash with an emphasis on heavy metal-bearing phases, Journal of Hazardous Materials, 187, pp. 534-543 (2011)

10. P. Piantone, F. Bodenan, L. Chatelet-Snidaro: Mineralogical study of secondary mineral phases from weathered MSWI bottom ash: implications for the modeling and trapping of heavy metals, Applied Geochemistry, 19, pp. 1891-1904 (2004)

11. R.M. Santos, G. Mertens, M. Salman, O. Cizer, T.V. Gerven: Comparative study of ageing, heat treatment and accelerated carbonation for stabilization of municipal solid waste incineration bottom ash in view of reducing regulated heavy metal/metalloid leaching, Journal of Environmental Management, 128, pp. 807-821 (2013)

12. Y.D. Jo, N.I. Um, G.C. Han, J.W. Ahn, K.H. Lee, B.C. Ban: Characteristic of chloride in municipal solid waste incineration (MSWI) bottom ash via washing process, The Korean Society for Geosystem Engineering, 44(2), pp. 127-134 (2007)

13. N.I. Um, G.C. Han, K.S. You, H.C. Cho, J.W. Ahn: Separation of ferrous materials from municipal solid waste incineration bottom ash, Journal of Korean Inst. of Resources Recycling, 16(3), pp. 19-26 (2007)

14. G. Pecqueur, C. Crignon, B. Quenee: Behaviour of cement-treated MSWI bottom ash, Waste Management, 21, pp. 229-233 (2001)

15. M. Chrysochoou and D. Dermatas: Evaluation of ettringite and hydrocalumite formation for heavy metal immobilization: Literature review and experimental study, Journal of Hazardous Materials, 136, pp. 20-33 (2006)

16. I. Rousselot, C. Taviot-Gueho, F. Leroux, P. Leone, P. Palvadeau, J.P. Besse: Insights on the structural chemistry of hydrocalumite and hydrotalcite-like materials: investigation of the series $\mathrm{CaM}^{3+}(\mathrm{OH})_{6} \mathrm{Cl} \cdot 2 \mathrm{H}_{2} \mathrm{O}\left(\mathrm{M}^{3+}: \mathrm{Al}^{3+}, \mathrm{Ga}^{3+}, \mathrm{Fe}^{3+}\right.$, 
and $\mathrm{Sc}^{3+}$ ) by X-ray powder diffraction, Journal of Solid State Chemistry, 167, pp. 137-144 (2002)

17. G.C. Han, N.I. Um, K.S. You, H.C. Cho, J.W. Ahn: Change of mineral phases in carbonation reaction of MSWI bottom ash, Geosystem Engineering, 12(1), pp. 21-25 (2009)

18. G. Gadikota, C. Natali, C. Boschi, A.H. Alissa Park: Morphological changes during enhanced carbonation of asbestos containing material and its comparison to magnesium silicate minerals, Journal of Hazardous Materials, 264, pp. 42-52 (2014)

19. J.A. Meima, R.D. Weijden, T.T. Eighmy, R.N.J. Comans: Carbonation processes in municipal solid waste incinerator bottom ash and their effect on the leaching of copper and molybdenum, Applied Geochemistry, 17, pp. 1503-1513 (2002)

20. J.M. Chimenos, A.I. Fernandez, L. Miralles, M. Segarra, F. Espiell: Short-term natural weathering of MSWI bottom ash as a function of particle size, Waste Management, 23, pp. 887-895 (2003)

21. K.H. Lee, J.W. Ahn, H.C. Cho, K.S. You, G.C. Han, N.I. Um: Encapsulation of municipal solid waste incineration bottom ash to immobilize $\mathrm{Cu}$ and $\mathrm{Pb}$ via carbonation reaction, Solid State Phenomena, 124-126, pp. 1709-1712 (2007)

22. N.I. Um, S.Y. Nam, J.W. Ahn: Effect of accelerated carbonation on the leaching behavior of $\mathrm{Cr}$ in municipal solid waste incinerator bottom ash and the carbonation kinetics, Materials Transactions, 54(8), pp. 1510-1516 (2013)

23. E. Alvarez-Ayuso, A. Garcia-Sanchez, X. Querol: Adsorption of $\mathrm{Cr}(\mathrm{VI})$ from synthetic solutions and electroplating wastewaters on amorphous aluminium oxide, Journal of Hazardous Materials, 142, pp. 191-198 (2007) 